\title{
心拍数変動からみた 重症心身障害者の循環調節機能
}

原 著

\begin{tabular}{|c|c|c|}
\hline 三田勝已*1 & 赤滝 久美*1 & 伊藤 晋彦*1 \\
\hline 渡 壁＼cjkstart誠*1 & 久野 弘 明*3 & 高橋 由美*4 \\
\hline
\end{tabular}

Key words : 心拍数変動 (heart rate variability), 循環調節 (cardiovascular regulation), 自律神経 (autonomic nerve), 障害者 (disabled persons)

要旨 心拍数変動からみた重症心身障害者の循環調節機能 $\begin{array}{llll}\text { 三田勝己 } & \text { 赤滝久美 } & \text { 伊藤晋彦 鈴木伸治 } \\ \text { 渡壁 誠 } & \text { 久野弘明 } & \text { 高橋由美 } & \text { 中村博志 }\end{array}$

本研究では，長期臥床の重症心身障害者を対象に，抗重力姿勢（座位）および下 半身陰圧負荷に対する心拍数の変化を測定し，その心拍数変動を手がかりに彼らの 循環調節機能を分析した. その結果, 日々の生活のなかで受動的であっても座位を 経験している重症者は健常者と同様な心拍数反応がみられたが，それは健常者より 緩慢であった．これは循環調節にかかわる自律神経の機能低下を示すものであり， 副交感神経系の方がより機能低下の進行を推察させた。一方，全くの誛たきりの重 症者は健常者と逆の反応がみられ，自律神経系の機能不全をうかがわせた．

\section{リハ医学 $33: 554-561 ， 1996$}

\section{はじめに}

重症心身障害児・者（重症者と略す）の多くは日常 の大半を臥位姿勢で過ごし，座位や立位などの抗重力 姿勢をとったり, 能動的に活発な身体活動を行うこと が少ない，そのため，重症者の心肺機能(全身持久力) は著しく低く ${ }^{1)}$ ，さらに，姿勢変化に対する循環調節 (起立耐性)といった健康の維持にかかわる基本的な機 能にまで弊害が及んでいる ${ }^{2,3)}$. 循環調節機能の改善を 図るためにはこれを的確に評価し，機能訓練プログラ ムを考える必要がある。しかし，一般に循環調節機能
を評価するには多くの機器と複雑な測定・処理を要す $3^{3)}$. 本研究は比較的簡便に測定できる心拍数を手が かりに循環調節機能を分析しようとするものである. 特に心拍動ごとのゆらぎ, いわゆる心拍数変動 (heart rate variability：HRV) は循環調節にかかわる自律 神経活動を反映するといわれ，その無侵襲的な評価法 として注目されている4 6).

本研究では，瘦たきり重症者を対象に，抗重力姿勢 や下半身陰圧負荷法を用いて循環系に重力負荷を加え た際の心拍数の変化を測定し，これを手がかりに循環 調節機能，とりわけ，これにかかわる自律神経活動を 分析することとした。

1996 年 4 月 5 日受付, 1996 年 6 月 2 日受理

*1愛知県心身障害者コロニー発達障害研究所 $/$ T 480-03 愛知県春日井市神屋町 713-8

*2伊豆医療福祉センター/T 410 静岡県田方郡菲山町寺家 202

${ }^{* 3}$ 中部大学 $/$ 个 487 愛知県春日井市松本町 1200

*4名古屋大学 $/$ T 464-01 愛知県名古屋市千種区不老町 65

${ }^{* 5}$ 日本女子大学 $/=112$ 東京都文京区目白台 2-8-1 
表 被検者特性

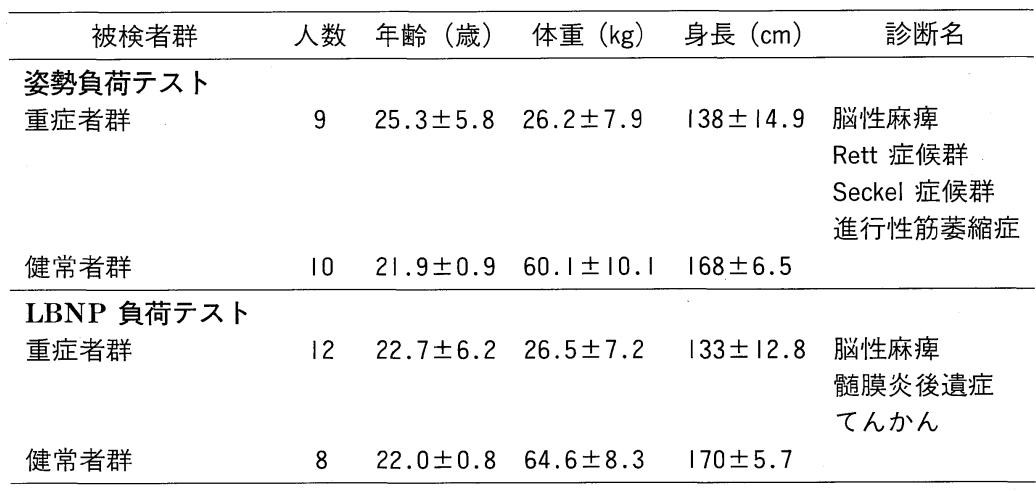

\section{心拍数の測定と処理}

\section{1 被検者}

被検者は 5 年以上寝たきりの重症者 21 名であり, 対 照群として概ね同年齢域の健常者 18 名を用いた。被検 者あるいは被検者の保護者には，本テストの実施に先 立ち，その趣旨ならびに内容について説明し，同意を 得た。被検者の年齢, 体格, 診断名は表に示した。重 症者は自力の姿勢保持能力や移動能力を持たず, 日常 生活のなかで活動的な全身運動はみられなかった。

9 名の重症者と 10 名の健常者が座位による「姿勢負 荷テスト」に参加した。この重症者 9 名は寄り掛かり であれば座位がとれ，食事や保育の時間をこの姿勢で 過ごしていた。こうした抗重力姿勢をとる時間は 1 日 数時間であった.

残りの 12 名の重症者と 8 名の健常者は後述する「下 半身陰圧 (lower body negative pressure : LBNP) 負 荷テスト」を行った。この重症者 12 名のなかで 7 名は, 「姿勢負荷テスト」の重症者と同様に，寄り掛かりの座 位能力をもち, 日及食事や保育の数時間をこの姿勢で 過ごしていた。一方, 他の 5 名は四肢, 体幹の変形や 拘縮が著しく, 寄り掛かりの座位をとることすら困難 であり，1日中ほとんど臥床状態で過ごしていた．

以下, 姿勢負荷テストおよび LBNP 負荷テストに 参加した被検者群を次の略称で呼ぶ.

\section{1 ）姿勢負荷テスト}

DP 群 (disabled, posture)：重症者

NP 群 (normal, posture)：健常者

\section{2 ) LBNP 負荷テスト}

$\mathrm{DL}_{1}$ 群 (disabled, LBNP, 1) : 寄り掛かりの座位能

\section{力をもつ重症者}

$\mathrm{DL}_{2}$ 群 (disabled, LBNP, 2) : 寄り掛かりの座位能 力をもたず, ほとんど臥床状態の重症者 NL 群 (normal, LBNP) : 健常者

\section{2 手 順}

\section{1) 姿勢負荷テスト}

本テストでは，安静仰臥位を 5 分間とった後，寄り 掛かりの座位姿勢を 5 分間保持させた. 特に重症者に 対しては座位時の顔や皮膚の色に注意を払った.また， 重症者は四肢, 体幹の変形や拘縮のために長座位をと ることが困難な者が幾人かいた。こうした場合には各 個人専用の椅子を用い, さらに，クッションや砂囊な ぞを併用して姿勢の固定に努め, 可能な限り重力の影 響がより大きくなる姿勢を設定した。

\section{2 ) LBNP 負荷テスト}

LBNP 負荷法とは, 臥位で下半身を密閉した箱に入 れ，この内部を隇圧することによって血液を下肢に移 行させる方法である (図 1)。その結果, 臥位の状態で 循環系に対して座位や立位と同様な重力の影響を与え ることができる. LBNP を負荷するための密閉箱には 透明なアクリル樹脂製の蒲鉾型カプセルを用いた。こ れに被検者の下半身を挿入し, 腰部をネオプレンシー トで密閉した。陰圧の発生はカプセル内の空気を市販 の掃除機で吸引することによって行い，スライダック で電圧を変化させてその強度を調節した．

各被検者は仰臥位で下半身をLBNP 装置に挿入し, 無負荷状態を 5 分間と LBNP 負荷状態を 5 分間安静 保持した。カプセル内部の陰圧は $-20 \mathrm{mmHg}$ に設定 し,この強度をアネロイド気圧計で監視した。なお, 陰圧強度一 $20 \mathrm{mmHg}$ は以下のことを考慮して選ん 


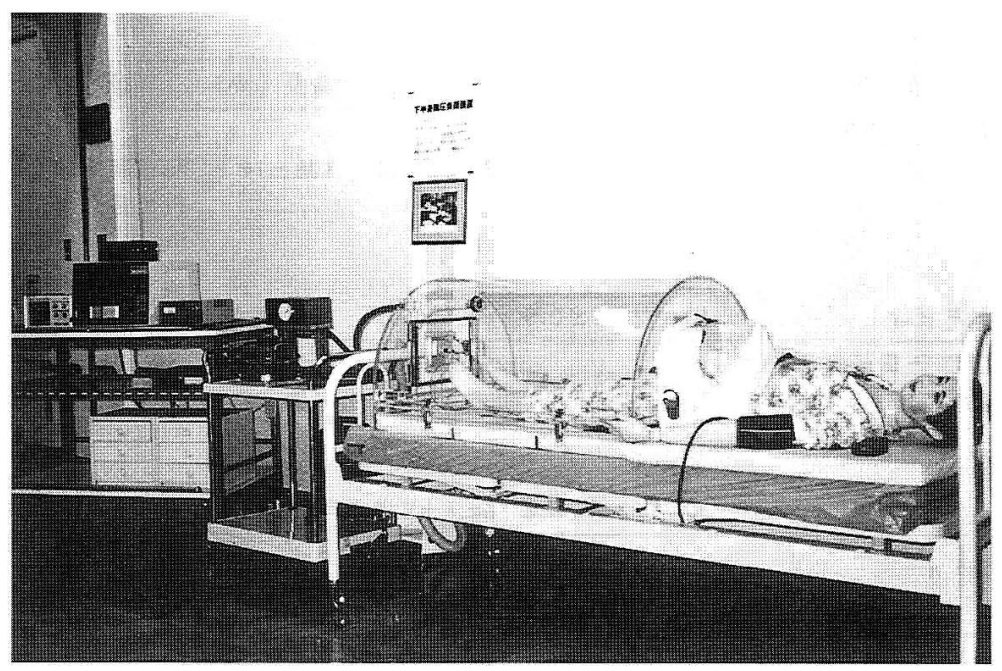

図 1 下半身陰圧負荷装置

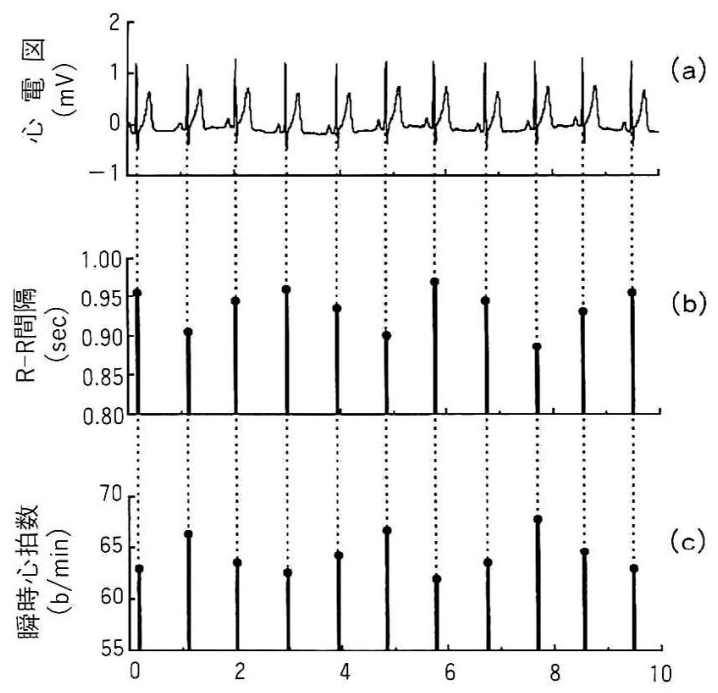

だ7,8). (1)起立性低血圧の発生を避けるためより軽度の 負荷にする，(2)健常者であればー $35 \mathrm{mmHg}$ まで通常 の血圧を維持できる, (3)LBNP 負荷に対する循環調節 反応が有意になるのはー $15 \mathrm{mmHg}$ からである。

\section{3 測定・処理}

2 種類の重力負荷テストの間，心電図を胸部単極誘 導し，連続して測定した。この心電図記録から R-R 間 隔を計測し，その逆数を求めて瞬時心拍数とした。 そ の後, 定常な 256 秒間の瞬時心拍数時系列に以下の処 理を行い, 平均心拍数と心拍数変動 (HRV) のパワー スペクトルを求めた。すなわち，瞬時心拍数の值を発 生時刻に沿って並べた時系列は等間隔に配列していな いので，通常のスペクトル解析法が適用できない。 そ のため,この瞬時心拍数時系列にスプライン関数を適

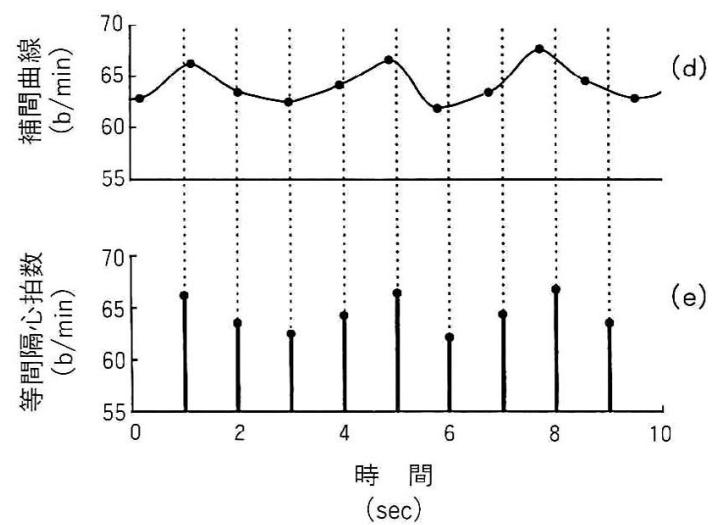

図 2 等間隔心拍数時系列の導出法 (a)心電区, ( $)$ R-R 間隔時系列, (c)瞬時心拍数時系列, (d)瞬時心拍数の補間曲線, (e)等間隔心拍数時系列
用して近似曲線を求め, 0.5 秒ごとに等間隔サンプリ ングして処理対象の原データとした（図 2)。次に，原 デー夕より平均心拍数を求め, その後, 原デー夕から 平均心拍数を引いて HRV 算出した，HRV のパ ワースペクトルは高速フーリエ変換法によって推定し (e) た.

これらの計算結果から，循環調節機能を評価する以 下の值を求めた，第 1 は平均心拍数 (MHR) である. 第 2 は HRV の全パワー (PT) であり， 0.02〜0.50 Hz のパワースペクトル密度を積算して求めた。第 3 は父 感神経指標 (ISN) であり，パワースペクトルの低域パ ワー $(0.02 \sim 0.15 \mathrm{~Hz})$ を高域パワー $(0.15 \sim 0.50 \mathrm{~Hz})$ で除した值である ${ }^{9,10)}$ ，第 4 は副交感神経指標 (IPN) 
(a)

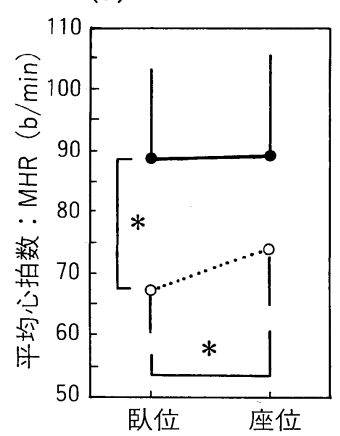

(c)

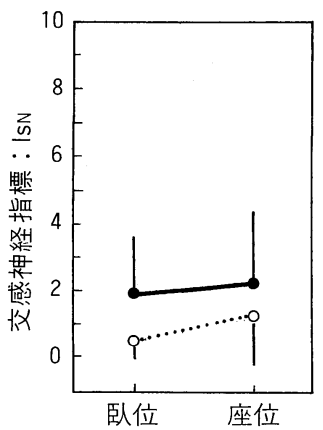

(b)

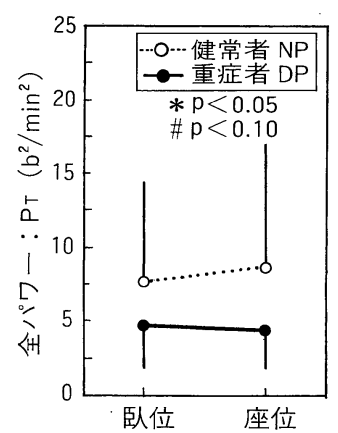

(d)

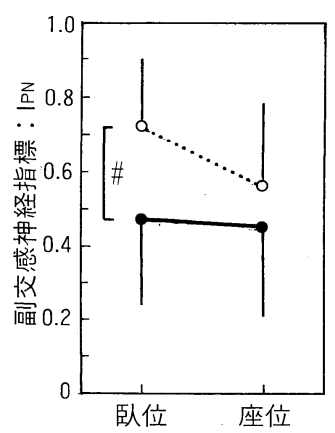

姿 勢

図 3 姿勢 (座位) 負荷テストにおける平均心拍 数と心拍数変動の変化

(a)平均心拍数, (b)全パワー, (c)交感神経指標, (d)副 交感神経指標

であり，高域パワーを全パワーで除した值である．

これら 4 つの評価パラメーターが被検者群間あるい は重力負荷の有無によって差があるか否かを統計学的 に検討するため, 分散分析を行った。 そして, その差 は $\mathrm{p}<0.05 を も っ て$ 統計学的に有意とした.

\section{結 果}

\section{1）姿勢負荷テスト}

まず，臥位時の平均心拍数 MHR をみると，重症者 $\mathrm{DP}$ 群の $88.6 \mathrm{~b} / \mathrm{min}$ は健常者 $\mathrm{NP}$ 群の $67.4 \mathrm{~b} / \mathrm{min}$ よ り有意に高い值を示した $(\mathrm{p}<0.05$, 図 $3(\mathbf{a})) . \mathrm{NP}$ 群 の座位時の MHR は臥位時に比べ $6.9 \mathrm{~b} / \mathrm{min}$ 有意に増 大した. DP 群は臥位, 座位の両姿勢間でほとんど変化 しなかった。

$\mathrm{HRV}$ に関して, DP 群の臥位時の全パワーPT は (a)

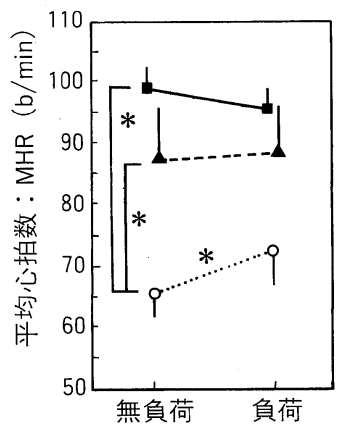

(c)

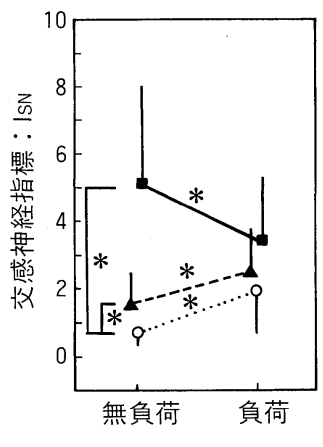

下半身陰圧負荷 $(-20 \mathrm{mmHg})$

\section{図 4 下半身陰圧負荷テストにおける平均心拍} 数と心拍数変動の変化

(a)平均心拍数, (b)全パワー, (c)交感神経指標，(d)副 交感神経指標

NP 群と比べて $62 \%$, 座位時で $50 \%$ と少なかったが, 統計学的には有意差を確認しなかった(図 $3(\mathbf{b}))$. 姿勢 負荷に対する反応をみると, NP 群は臥位と比較して 座位時に若干の増大 (14\%) を示した。DP 群では座位 において幾分か減少 $(-8 \%)$ した。

DP 群の交感神経指標 ISN は全般に NP 群より大き く, 逆に副交感神経指標 IPN は小さかった（図 3(c), (d)). NP 群の臥位から座位への変換に伴う ISN の増分 は 0.74 となったが，DP 群は 0.33 とその約半分で

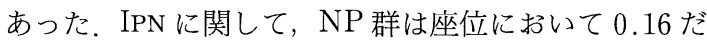
け減少した。一方，DP 群の座位負荷に対する IPN の 減少は 0.02 と極わずかであり, NP 群より明らかに少 なかった。

\section{2）LBNP 負荷テスト}

無負荷時の平均心拍数 MHR をみると, 重症者 2 群 $\left(\mathrm{DL}_{1}: 87.4 \mathrm{~b} / \mathrm{min}, \mathrm{DL}_{2}: 98.7 \mathrm{~b} / \mathrm{min}\right)$ は健常者 $\mathrm{NL}$ 群 $(65.7 \mathrm{~b} / \mathrm{min})$ より有意に高い值を示した (図 $4(\mathbf{a})$ ). 
LBNP 負荷に対して，NL 群は $7.0 \mathrm{~b} / \mathrm{min}$ の有意な上 昇を示したが， $\mathrm{DL}_{1}$ 群は $1.2 \mathrm{~b} / \mathrm{min}$ とわずかな上昇に 止まった. $\mathrm{DL}_{2}$ 群は逆に $3.2 \mathrm{~b} / \mathrm{min}$ だけ減少した。

$\mathrm{HRV}$ の全パワー PT は $\mathrm{DL}_{1}$ 群と NL 群が同等で あったが， $\mathrm{DL}_{2}$ 群は両群より 20〜25\%少なかった (図 $\mathbf{4}(\mathbf{b}))$. LBNP 負荷による PT の変化は 3 群ともほとん どみられなかった (NL : $3 \%, \mathrm{DL}_{1}:-4 \%, \mathrm{DL}_{2}:-$ $3 \%$ ).

無負荷時の交感神経指標 ISN に関して, 重症者 2 群 $\left(\mathrm{DL}_{1}, \mathrm{DL}_{2}\right)$ は NL 群より有意に大きかった (図 $\left.4(\mathbf{c})\right)$. LBNP 負荷に対する ISN の反応は $\mathrm{DL}_{1}$ 群が 0.97 , $\mathrm{NL}$ 群が 1.23 だけ有意に増大した. しかし, $\mathrm{DL}_{2}$ 群の ISN は 1.68 だけ減少し, 逆の変化を示した.

重症者 2 群の無負荷時の副交感神経指標 IPN は NL 群より小さく, その差は $\mathrm{DL}_{2}$ 群がより顕著であった。 また, $\mathrm{NL}$ 群と $\mathrm{DL}_{1}$ 群との差は統計学的傾向 $(\mathrm{p}<$ $0.10), \mathrm{DL}_{2}$ 群では有意差 $(\mathrm{p}<0.05)$ として確認され た。 LBNP 負荷による IPN の変化は, NL 群が 0.21 , $\mathrm{DL}_{1}$ 群が 0.12 だけ減少を示した。逆に $\mathrm{DL}_{2}$ 群では 0.03 だけわずかながら IPN の増大を認めた。

\section{考 察}

\section{1 循環系への負荷法}

これまで，健常者を対象とした循環調節機能に関す る研究では立位という重力負荷が広く用いられてい る.しかしながら, 本研究で対象とした寝たきりの重 症者はたとえ寄り掛かりであっても立位を保つことが 困難であった。このため, 本実験では負荷強度が小さ くなるものの, 座位による負荷法を用いることにした． また, デー夕の処理・分析は, 日常生活における座位 保持の有無, つまり, 重力負荷の経験の有無と関連づ けて行う予定であった。 ところが, 寄り掛かりであっ ても座位がとれる者は食事や保育の時間をこの姿勢で 過ごしていた。一方，座位のとれない，全くの寝たき りの重症者は拘縮や変形が著しく, 実験的に短時間寄 り掛かりの座位をとることすら困難な者が多かった。 そのため, 姿勢負荷テストでは, 寄り掛かりの座位能 力をもち, さらに, 日常生活の数時間を座位で過ごし ている者が対象となった。 そして，この姿勢負荷法の 欠点を補うために，臥位のままで循環系に負荷を加え ることができ, 重力負荷と同様な循環反応が得られる
LBNP 法 ${ }^{7,8)}$ を導入し, 日常生活に扔ける重力負荷の経 験の有無との関連についても分析に含めることにした のである，以下，本実験で得られた結果について考察 を加えていく.

\section{2 平均心拍数}

まず，無負荷時（姿勢負荷テストでの臥位あるいは LBNP 負荷テストでの無負荷) の平均心拍数を考え る。一般に臥位姿勢をとると，座位や立位のような抗 重力姿勢に比べて腎血流量が増加し, 体液調節ホルモ ンであるレニン・アンギオテンシン系が抑制される. このためナトリウムが多量に排出され，その結果とし て尿排泄が促進する ${ }^{11}$.さらに, 臥位の状態が長期に継 続すると，その期間に対応して体液の減少が進行し， これに伴って全血液量の減少が起きる，全血液量の減 少は 1 回拍出量さらに心拍出量の減少, 安静時心拍数 の上昇など循環系に有意な変化をもたらすことが明ら かにされている ${ }^{12)}$. 本研究でも重症者群は無負荷臥位 時において健常者群より有意に高い心拍数を示した. この特徵は健常者を対象に $4 \sim 6$ 週間の実験的臥床を

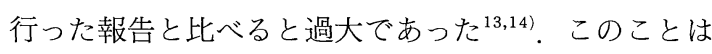
本重症者群の臥床状態が遙かに長く, これに伴う全血 液量の減少が著しいことを推察させる.

次に, 循環系に重力負荷を加えた際の心拍数反応に 注目する．健常な機能であれば，心拍数は座位や立位 に対して有意な増大を示す. 本研究の健常者群の心拍 数反応はこれを確認させる。しかし, 姿勢負荷テスト の重症者 DP 群, LBNP 負荷テストの $\mathrm{DL}_{1}$ 群の心拍 数は健常者群のような明確な増大がみられず, $\mathrm{DL}_{2}$ 群 に至っては減少傾向すら認められた. Blamick ら ${ }^{13)}$ Chobanian $ら^{14)}$ は, 数週間の臥床実験を行い, 立位負 荷に対する心拍数反応を臥床前後で観察した結果, 臥 床後では臥床前に比べその増加反応が大きくなると報 告している. 彼らはこの現象を臥床に伴う 1 回拍出量 の減少に対し, 心拍出量を維持するための過大な補償 作用であると解釈した。 また，その際に血圧を維持で きなかった者もみられ，全血液量の減少が循環調節機 能を低下させると述べている。一方, Convertino ら ${ }^{15)}$ による 30 日間臥床の報告では本実験の DP 群および $\mathrm{DL}_{1}$ 群と同様の結果がみられる。つまり, 彼らの報告 では, 重力負荷に対する心拍数の増分が臥床前と比心゙ 少なくなっていた，彼らはこの結果から臥床状態が長 期にわたると圧反射に機能不全が起きると結論づけ 
た.このことは長期臥床に伴う循環調節機能の低下が 全血液量の減少によるという意見に加え, 圧反射機構 の不全にも起因することを示唆するものである．本研 究の重症者 $\mathrm{DP}$ 群および $\mathrm{DL}_{1}$ 群の心拍数反応は彼ら の報告を論拠とすれば納得しうる。ささらに, $\mathrm{DL}_{2}$ 群が 本来の心拍数反応とは逆の結果を示したことは, 彼ら の循環調節システムのいずれかに重篤な障害が生じて いることを推察させる.

\section{HRV のパワー}

上で議論した重力負荷に対する心拍数の増大反応は 血圧維持のための補償作用の一つであり, その作用は 自律神経によって調節されている. 本研究ではこの自 律神経活動を HRV のパワースペクトルからうかがう ことにした，そこでまず，本実験における HRV の全 パワーについて考える. 健常者群と重症者群の全パ ワーの大きさを比較すると, 姿勢負荷テストにおける 重症者 DP 群の全パワーは健常者 NP 群の $50 \sim 60 \%$ であり，LBNP 負荷テストでは重症者 $\mathrm{DL}_{2}$ 群が 70 80\%であった. 全パワーの減少は高齢者にもみら れることが数多く報告されており，これは加齢に伴う 自律神経の機能低下と関連があると推察されてき $た^{16 \sim 18)}$. また, HRV の減少は糖尿病による自律神経 障害, 遺伝性自律神経症, 多発性硬化症の患者などで も明らかにされている19,20).こうした知見は, HRVの パワー, つまり大きさの減少が, 生理的な加齢であれ 特定の疾患によるものであっても, 自律神経の機能低 下を反映しうることを示唆する。 そして, 本重症者に も同様な傾向がみられたことは自律神経に何らかの機 能低下が存在することを推察させる.

次に, 重力負荷を加えた際の全パワーの変化を考え る. 本研究の被検者と同年齢域である $20 \sim 40$ 歳の健常

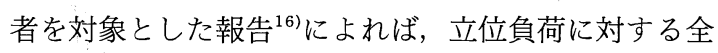
パワーは臥位に比べて有意に増大した。一方，加齢に 伴う機能低下が想定される 60 80 歳の高齢者でも有 意な増加がみられたものの, 若年者に比べると少な かった。 また, 18〜35 歳と 71〜94 歳を比較した研究 ${ }^{17)}$ では，若年者は有意な増加を示したが，高齢者では逆 に減少した。こうした知見は, 全パワーの変化が重力 負荷に対する自律神経の反応性の良否を大局的に反映 することを示したといえる。本実験における健常者群 の全パワーは姿勢負荷や LBNP 負荷に反応して若干 増大したが，重症者群では幾分か減少を示した。この
反応は従来の報告と比べると明確でなかったが，それ は負荷強度の違い, つまり, 立位に比べて座位が負荷 強度として軽度であったためと思われる。しかしなが ら, 本実験の結果は先行研究と矛盾する傾向ではない と考える.

\section{4 交感・副交感神経活動}

循環調節にかかわる自律神経は重力負荷に対して交 感神経が促通し, 副交感神経が抑制される。これまで にも高齢者や患者の HRV のパワースペクトルの特徵 から自律神経活動の低下や不全が論議されてきた が $^{16 ~ 20)}$, 交感・副交感神経のいずれに起因するかは言 及されていない，そこで，重症者群で推察された自律 神経障害が交感神経, 副交感神経のいずれの神経系と 関係しているかを考える，なお，交感・副交感神経の 相互作用が HRV に反映されることは前述した. HRV のパワースペクトルにおける $0.15 \mathrm{~Hz}$ 以上の高域パ ワーは副交感神経活動を反映し, $0.15 \mathrm{~Hz}$ 以下の低域 パワーは交感・副交感神経の相互活動を示すことが明 らかにされている ${ }^{4 \sim 6)}$. 一般に HRV の大きさには個人 差があるので, 高域パワーを全パワーで規格化した副 交感神経指標 IPN が定義されている。また, 低域パ ワーと高域パワーの比によって交感神経指標 ISN を定 義し，交感神経活動を推定する指標として使われてい $る^{9,10)}$. 本研究でも重症者と健常者では HRV の大きさ に差がみられたので, 上記の指標を利用した。

姿勢負荷テストおよび LBNP 負荷テスト共に, 重 症者群の無負荷臥位時の ISN は健常者群に比べて大き く, IPNは小さい值を示した，また，その特徵は LBNP 負荷テストの $\mathrm{DL}_{2}$ 群が最も顕著であった. 重力負荷に 対するISN および IPN の反応に関しては，姿勢負荷 テストの重症者 DP 群および LBNP 負荷テストの $\mathrm{DL}_{1}$ 群が健常者群と同様な反応傾向を示した（ISN は 増加, IPN は減少)。しかじ, それらの変化量は重症者 群と健常者群との間で顕著な違いがあった。すなわち, 姿勢負荷テストの重症者 DP 群をみると, ISNの増加量 は健常者群の $45 \%$, IPN の減少量は $13 \%$ あり, 交 感・副交感の両神経系とも健常者群より変化が少なく, 特に副交感神経系の方がより緩慢であった。また, LBNP 負荷テストの $\mathrm{DL}_{1}$ 群の場合も, ISN の増加量 は健常者群の $79 \%$, IPNの減少量は $57 \%$ となり, 姿勢 負荷テストと同様な特徵が認められた。さらに, LBNP 負荷テストの重症者 $\mathrm{DL}_{2}$ 群にいたっては, 重力負荷に 
対する交感神経および副交感神経指標の反応が健常者 群および他の重症者群のそれとは逆転した。

神経電図法によって筋交感神経パルスを直接記録し

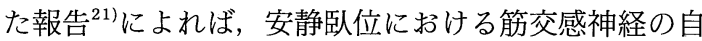
発性発射は若年者に比べて高齢者の方が有意に六進し ており，さらに，立位負荷に対する発射頻度の変化が 少なかった。 また，同様な特性が血漿ノルエピネフリ ン濃度についても示されている ${ }^{22,23)}$ 。これらの知見は 交感神経の機能低下を証明したものといえるが，これ と拮抗的な副交感神経にも同様な変化が発生している ことが想像される。

そこで，HRV に関する先行研究と本実験結果をも とに以下のことが推察される。つまり重症者 DP 群や $\mathrm{DL}_{1}$ 群では循環調節にかかわる自律神経活動が低下 しており，それはより副交感神経系に進行していると 推察される。しかし，健常者と同様な反応パターンを 示したことはある程度の機能が残存していると思われ る。なお，この 2 群は受動的ながら座位がとれ，日常 生活のなかでもその姿勢をとる機会があった.このこ とは循環調節機能の維持に大きな役割を果たしていた と考える。一方， $\mathrm{DL}_{2}$ 群は LBNP 負荷に交感神経指 標の減少，副交感神経指標の増大を示し，健常な機能 による反応とは全く逆であり，交感・副交感神経の両 神経系に機能不全を推察させる. $\mathrm{DL}_{2}$ 群はほとんど寝 たきりであり，日々の生活のなかで重力負荷を経験す る機会は皆無に等しかった。 こうした生活環境も重篤 な自律神経障害に導いた要因の一つであると思われ る.

謝辞：本研究の遂行に際して多大なご協力をいただいた 国立療養所足利病院, 北海道療育園の関係諸氏に深謝いた します。本研究の一部は「厚生省精神・神経疾患研究委託 費 (5 指-9)」, 「三菱財団社会福祉助成金」によって行わ れた。

\section{文 献}

1) Mita K, Akataki K, Miyagawa T, Koyama K, et al : Assessment of daily physical activity levels of severely disabled persons using heart rate series. Front Med Biol Eng 3:17-25, 1991.

2) Gorbien MJ, Bishop J, Beers MH, Norman D, et al: Iatrogenic illness in hospitalized elderly people. J Am Geriatr Soc 40:1031-1042, 1992.

3) Mita K, Akataki K, Itoh K, Ishida $Y$, et al : Hemodynamic and hormonal changes during lower body negative pressure in bedridden disabled patients. Sports Med Training Rehabil 3 :
147-156, 1992.

4) Sayers B : Analysis of heart rate variability. Ergonomics 16:17-23, 1973.

5) Kintey RI, Rompelman O : The Study of Heartrate Variability. Clarendon Press, Oxford, 1980.

6) Akselrod S, Gordon D, Ubel FA, Shannon DC, et al : Power spectrum analysis of heart rate fluctuation: a quantitative probe of beat-to-beat cardiovascular control. Science 213:220-222, 1981.

7) Sather TM, Goldwater DJ, Montgomery LD, Convertino VA: Cardiovascular dynamics associated with tolerance to lower body negative pressure. Aviat Space Environ Med 57 : 413-419, 1986.

8) Tripathi A, Nadel ER : Forearm skin and muscle vasoconstriction during lower body negative pressure. J Appl Physiol 60 : 1535-1541, 1986.

9) Pagani M, Lombardi F, Guzzetti S, Rimoldi O, et al: Power spectral analysis of heart rate and arterial pressure variabilities as a marker of sympatho -vagal interaction in man and conscious dog. Circ Res $59:$ 178-193, 1986.

10) Yamamoto $Y$, Hughson RL, Nakamura $Y$ : Autonomic nervous system responses to exercise in relation to ventilatory threshold. Chest $\mathbf{1 0 1}$ (Suppl) : 206S-210S, 1992.

11) Melada GA, Goldman RH, Luetscher JA, Zager PG : Hemodynamics, renal function, plasma renin, and aldosterone in man after 5 to 14 days of bed rest. Aviat Space Environ Med 46:1049-1055, 1975.

12) Stevens PM, Miller PB, Gilbert CA, Lynch TN, et al: Influence of longterm lower body negative pressure on the circulatory function of man during prolonged bed rest. Aerospace Med $37: 357-367$, 1966.

13) Blamick CA, Goldwater DJ, Convertino VA : Leg vascular responsiveness during acute orthostasis following simulated weightlessness. Aviat Space Environ Med 59:40-43, 1988.

14) Chobanian AV, Lille RD, Tercyak A, Blevins P : The metabolic and hemodynamic effects of prolonged bed rest in normal subjects. Circulation XLIX : 551-559, 1974.

15) Convertino VA, Doerr DF, Eckberg DL, Fritsch JM, et al: Head-down bed rest impairs vagal baroreflex responses and provokes orthostatic hypotension. J Appl Physiol 68: 1458-1464, 1990.

16) Simpson DM, Wicks $R$ : Spectral analysis of heart rate indicates reduced baroreceptor-related heart rate variability in elderly persons. J Gerontol 43 : M21-M24, 1988.

17) Lipsitz LA, Mietus J, Moody GB, Goldberger AL : Spectral characteristics of heart rate variability before and during postural tilt : relations to aging and risk of syncope. Circulation 81:1803-1810, 1990. 
18) Waddington JL, MacCulloch MJ, Sambrooks JE : Resting heartrate variability in man declines with age. Experientia $35: 1197-1198,1979$.

19) Maayan C, Axelrod FB, Akselrod S, Carley DW, et al : Evaluation of autonomic dysfunction in familial dysautonomia by power spectral analysis. J Auton Nerv Syst $21: 51-58,1987$.

20) Neubauer B, Gundersen HJG : Analysis of heart rate variations in patients with multiple sclerosis. J Neurol Neurosurg Psychiatry 41:417-419, 1978.
21) Iwase $S$, Mano $T$, Saitou $M$, Nagasaka $T$ : Effects of aging on muscle sympathetic nerve activity. Prog Biometeorol $7: 73-78,1989$.

22) Fiolica V, Kem DC : Plasma norepinephrine, blood pressure and heart rate response to graded change in body position. Aviat Space Environ Med 56 : 1166-1171, 1985.

23) Wallin BG, Sundlof G, Eriksson BM, Dominiak P, et al: Plasma noradrenaline correlates to sympathetic muscle nerve activity in normotensive man. Acta Physiol Scand 111:69-73, 1981.

\title{
Assessment of Cardiovascular Regulation in Persons with Severe Multiple Disabilities using Heart Rate Variability \\ by
}

\author{
Katsumi M ITA $^{* 1}$, Kumi AKaTaKI ${ }^{* 1}$, Kunihiko IToH ${ }^{* 1}$, Nobuharu Suzuki ${ }^{* 2}$, \\ Makoto W ATAKabe $^{* 1}$, Hiroaki Kuno ${ }^{* 3}$, Yumi TAKahashi ${ }^{* 4}$, Hiroshi NaKamura ${ }^{* 5}$ \\ from \\ ${ }^{* 1}$ Institute for Developmental Research, Aichi Human Service Center, \\ ${ }^{* 2}$ Izu Rehabilitation and Welfare Center for Children with Disabilities, \\ ${ }^{* 3}$ Chubu University, \\ ${ }^{* 4}$ Nagoya University, \\ *5 Japan Women's University
}

(Jpn J Rehabil Med $33: 554-561,1996)$

Heart rate variabilities (HRV) during antigravitational posture test and lower body negative pressure test were measured in 21 bedridden patients with severe multiple disabilities and 18 normal persons to investigate their autonomic activity in cardiovascular regulation. After a control period of 5 min of supine, each subject underwent an orthostatic sitting test or a lower body negative pressure test of $-20 \mathrm{mmHg}$ for $5 \mathrm{~min}$. From the power spectral density of the HRV, the sympathetic and parasympathetic activities were assessed by the ratio of low frequency power in 0.02 to $0.15 \mathrm{~Hz}$ to high frequency power in 0.15 to $0.5 \mathrm{~Hz}$, and the normalized high frequency power by total power in 0.02 to $0.5 \mathrm{~Hz}$, respectively. The results suggest that the autonomic inactivity in cardiovascular regulation for the disabled persons appears to be caused not only by a decrease in total blood volume but also by dysfunction of baroreflex probably due to the prolonged recumbency. Furthermore the deconditioning of their autonomic function seems to be associated more with parasympathetic deterioration. The degree of the orthostatic intolerance may also be linked to their lack of daily exposure to the gravitational forces being provided even by passive sitting posture. 